\title{
Formação e informação
}

Cada um de nós reúne um legado de atitudes clínicas que provêm dos ensinamentos de nossos mestres, de nossa escola ortodôntica. Essa dependência, no início, é fundamental para nortear os primeiros passos da carreira. Durante os anos que dura o curso de especialização ou de mestrado, agrega-se uma bagagem enorme de informações para sustentar a atividade prática. Normalmente, o ortodontista neófito procura seguir à risca as orientações recebidas, reconhecendo que as mesmas são conseqüências das experiências pessoais positivas dos seus professores, aliadas às evidências científicas vigentes. É claro que, depois de alguns anos de trabalho, cada um se adaptará com as próprias experiências clínicas, incorporando as inovações e dispositivos que surgem. A formação sólida da especialidade propicia um senso crítico profissional que questionará cada detalhe das novidades. Contando já com alguma experiência, o profissional procurará perceber vantagens e desvantagens, com bom senso e, nas circunstâncias nas quais as novidades entrarem em choque com sua formação, procurará comedidamente verificar sua aplicabilidade. Informando-se mediante as pesquisas publicadas, comunicações consistentes em Congressos e encontros do gênero, o ortodontista poderá aderir ou não à mudança de atitude, com o benefício precípuo de seus pacientes em mente. Aquelas abordagens adotadas no início de carreira vão gradativamente mudando e se lapidando, migrando para o aprimoramento e para a excelência clínica. Então, quando por fim encontramos nossos grandes mestres, depois de 5, 10 ou 15 anos, não nos surpreende que eles também tenham adotado outras formas de conduta, tal como também acontece com nossos colegas de turma.

Portanto, se num momento de reflexão notarmos que ainda praticamos os mesmos ensinamentos de 5 ou 10 anos, ou menos, sem mudar absolutamente nada, é porque, provavelmente, já passou da hora de freqüentarmos um evento e/ou praticarmos mais o hábito salutar de ler. Que tipo de material estou usando? Estou satisfeito com as finalizações dos meus casos? Como será que está aquele caso cirúrgico de 15 anos atrás? Que dados podemos fornecer aos pacientes sobre o potencial de recidiva? $\mathrm{E}$ assim por diante, poderíamos preencher uma folha de perguntas que todo mundo gostaria de saber responder. Algumas delas já apresentam correspondência na literatura e outras estão sendo consistentemente estudas. Pensando nisso, nesse número da Revista trazemos alguns artigos que investigam os materiais que temos empregado, discutindo, por exemplo, a eficiência do desenho da base dos braquetes com relação à qualidade de retenção.
Ainda em debate, é abordada a quantidade de liberação de níquel pelos braquetes, fator ligado ao seu potencial alergênico. Publicamos também um ensaio sobre a viabilidade clínica do "self-etching" para a colagem dos acessórios ortodônticos. Explorando os novos materiais, Ianni Filho e colaboradores ilustram o uso das fibras reforçadas por resina, na segunda parte do artigo prévio. Uma solução cirúrgica para implantes que tem sua posição inadequada, é exposta num relato inédito de caso, retração cada vez mais envolvida na prática reabilitadora.

No quesito diagnóstico e planejamento apresentamos um artigo que questiona o uso da radiografia PA para avaliação do desvio da linha mediana em casos de Classe II, subdivisão, e também uma publicação sobre as abordagens diante de retenção prolongada de dentes decíduos. Em outro artigo, a relação das más oclusões de Angle com a discrepância de Bolton é esclarecida. Destacamos o valor clínico do artigo de Maia e Rossato, que versa sobre a alteração do ângulo nasolabial após os tratamentos ortodônticos com quatro extrações, juntamente com o artigo sobre a estabilidade a curto prazo do reposicionamento anterior cirúrgico da maxila, apresentado por Tavares e Passeri.

Finalmente, o Tópico Especial traz um dos instrumentos para avaliação de nossas atitudes e resultados. Os métodos de sobreposição cefalométrica, à exemplo do método de Ricketts apresentado, propiciam entender, e mesmo que com alguma limitação, o que conseguimos alterar, somado ao padrão de crescimento individual. Além de propósitos de pesquisa, consiste em uma forma de aprendizado ímpar, à nossa inteira disposição, após cada caso clínico concluído. Já que o assunto é aprimoramento, não poderíamos deixar de mencionar os esclarecimentos apresentados na secção entrevista, sobre os exames de qualificação da ABOR, o "Board" Brasileiro de Ortodontia. Entendemos que todas as iniciativas que visam o engrandecimento e a excelência de nossa profissão, devem ser valorizadas.

Tão vital quanto uma sólida formação é a sua alimentação com boas e novas informações. $\mathrm{O}$ aprimoramento constante nos torna mais satisfeitos e felizes, especialmente porque seres humanos próximos, os nossos pacientes, podem desfrutar do melhor. Toda equipe da Revista Dental Press de Ortodontia e Ortopedia Facial sente-se honrada de poder compartilhar deste processo. Esperamos que você leitor aproveite as novas informações!

\section{Adilson Luiz Ramos} Editor 